\title{
Sobre a moléstia de Nabuco, ainda*
}

\author{
On Nabuco's malady, still
}

\author{
André Jobim Martins \\ Doutorando em História pela \\ Pontifícia Universidade Católica do Rio de Janeiro \\ andrejmartins@gmail.com
}

\begin{abstract}
Resumo: Na autobiografia Minha formação, publicada em 1900, Joaquim Nabuco expõe em diversas passagens uma "instabilidade" entre o Brasil e a Europa, que é também uma oposição entre particular e universal, entre sentimento e pensamento. Este artigo procura analisar alguns desdobramentos do dilema, a fim de melhor compreender, por um lado, suas diversas configurações, dentro do livro, e, por outro, com o subsídio adicional de outras fontes, observar como o referido dilema se manifestou em certos momentos da trajetória do político, escritor e diplomata pernambucano. Na seção final, proponho que a questão seja encarada como um caso inserido numa problemática mais abrangente em torno do nexo entre subjetividade e formações mentais.
\end{abstract}

Palavras-chave: Joaquim Nabuco, Mário de Andrade, literatura brasileira.

\begin{abstract}
In an autobiography titled Minha formação, first published in 1900, Joaquim Nabuco exposes in numerous passages an "instability" between Brazil and Europe, which also accounts for the opposition between the particular and the universal, as well as that between feeling and thought. This article aims to analyse various developments of the dilemma, aiming to better understand, on the one hand, different forms of what Nabuco describes in the book and, on the other hand, with the aid of fonts apart from the book, observe how the aforementioned dilemma unfolds in certain moments over the course of the author's life. In the final section, the reader shall find an interpretation of the theme as a particular case of a broader problem concerning the nexus between subjectivity and mental constructs.
\end{abstract}

Keywords: Joaquim Nabuco, Mário de Andrade, Brazilian literature.

\footnotetext{
* Financiamento: Conselho Nacional de Desenvolvimento Científico e Tecnológico (CNPq).
} 
I.

O episódio é bastante conhecido. Em 22 de novembro de 1924, um jovem Carlos Drummond de Andrade escrevia, aflito, a um já ilustre Mário de Andrade. Confessava sentir reeditar, talvez em modo farsesco, a "velha tragédia de Joaquim Nabuco":

Não sou ainda suficientemente brasileiro. Mas, às vezes, me pergunto se vale a pena sê-lo. Pessoalmente, acho lastimável essa história de nascer entre paisagens incultas e sob céus pouco civilizados. Tenho uma estima bem medíocre pelo panorama brasileiro. [...] É que nasci em Minas, quando devera nascer (não veja cabotinismo nessa confissão, peço-lhe!) em Paris. [...] Sabe de uma coisa? Acho o Brasil infecto. Perdoe o desabafo, que a você, inteligência clara, não causará escândalo. O Brasil não tem atmosfera mental; não tem literatura; não tem arte; tem apenas uns políticos muito vagabundos e razoavelmente imbecis ou velhacos. [...] Desculpe se vou estender-lhe ante os olhos os cenários da velha tragédia de Joaquim Nabuco, um pouco deteriorados... [...] Sou hereditariamente europeu, ou antes: francês: amo a França como um ambiente propício, etc. Tudo muito velho, muito batido, muito Joaquim Nabuco. [...] Quis apenas justificar a posição em que se encontram muitas criaturas honestas, inteligentes e cultas, em face ao apertado dilema: nacionalismo ou universalismo (Apud FROTA, 2003: 56-60).

Mário respondeu ao jovem mineiro com uma admoestação bem-humorada:

[V]ocê fala em apertado dilema: nacionalismo ou universalismo. Tudo errado. [...] não existe essa oposição entre nacionalismo ou universalismo. Você fala na "tragédia de Nabuco, que todos sofremos". Engraçado! Eu há dias escrevia numa carta justamente isso, só que de maneira mais engraçada de quem não sofre com isso. Dizia mais ou menos: "o doutor Chagas descobriu que grassava no país uma doença que foi chamada moléstia de Chagas. Eu descobri outra doença, de que todos estamos infeccionados: a moléstia de Nabuco" (Ibidem: 70).

Naquele mesmo ano, Mário retomaria o mote da "moléstia" numa entrevista, estendendo sua censura a toda a intelectualidade brasileira: "Moléstia de Nabuco é isso de vocês andarem sentindo saudade do cais do Sena em plena Quinta de [sic] Boa Vista 
e é isso de você falar dum jeito e escrever covardemente colocando o pronome carolinamichaelismente. Estilize a sua fala, sinta a Quinta de Boa Vista pelo que é e foi e estará curado da moléstia de Nabuco" (Apud SANTIAGO, 2006: 18).

Se Carlos admitia que o problema já era "velho" e "batido" e o expunha na forma de uma “confissão", Mário declara tê-lo superado e o diagnostica zombeteiramente como doença tropical, análogo psicológico do mal de Chagas. Ambos veem em Nabuco um ícone de um passado a ser superado, tarefa que cabia ao florescente movimento modernista brasileiro. Drummond, contudo, ainda que visse algo de negativo no europeísmo de Nabuco, não via solução ao dilema. Mário indica-lhe, em sua resposta, o caminho da cura: trata-se de esquecer o "primitivismo" da Belle Époque, e "desprimitivar o país, acentuar a tradição, prolongá-la, engrandecê-la" (Apud FROTA, 2003: 70), parar de "macaquear" as "obras menores" de outras civilizações, esquecer o angustiado aspirar a ser e entregar-se ao ser brasileiro. "Nada de dizer: se um dia eu for nacional, serei nacional. A graça divina depende da nossa cooperação, dizem os tratadistas católicos" (Ibidem: 71).

II.

Voltemos à moléstia de Nabuco. Quando Carlos e Mário usam respectivamente as expressões "tragédia de Joaquim Nabuco" e "moléstia de Nabuco" para dar nome à euromania dos brasileiros letrados incapazes de se identificar com seu país - sentimento que em Drummond o leva à declaração de que "devera nascer em Paris" -, aludem à autobiografia Minha formação, publicada pelo estadista pernambucano em 1900. Mais especificamente, há boa razão para acreditar que, ao fazerem de Nabuco a caricatura de uma fixação neurótica na Europa, os modernistas remetem ao quarto capítulo do livro, "Atração do Mundo". Ali, Nabuco apresenta exemplarmente aquilo que Drummond chama de "dilema" entre "nacionalismo" e "universalismo" (sendo o "universal" coincidente com a Europa). Os termos da discussão de Carlos e Mário ficam mais claros quando relemos a passagem mais conhecida do capítulo:

Estamos assim condenados à mais terrível das instabilidades, e é isto o que explica o fato de tantos sul-americanos preferirem viver na Europa... [...] A instabilidade a que me refiro, provém de que na América falta à paisagem, à vida, ao horizonte, à arquitetura, a tudo o que nos cerca, o fundo histórico, a 
perspectiva humana; que na Europa nos falta a pátria, isto é, a fôrma em que cada um de nós foi vazado ao nascer. De um lado do mar sente-se a ausência do mundo; do outro, a ausência do país. O sentimento em nós é brasileiro, a imaginação europeia. As paisagens todas do Novo Mundo, a floresta amazônica ou os pampas argentinos, não valem para mim um trecho da Via Ápia, uma volta da estrada de Salerno a Amalfi, um pedaço do Cais do Sena à sombra do velho Louvre. No meio dos luxos dos teatros, da moda, da política, somos sempre squatters, como se estivéssemos ainda derribando a mata virgem (NABUCO, 2012 [1900]: 70).

Para este beletrista de 1900, não há escândalo em afirmar que a paisagem tropical, tão alardeada pelo ufanismo de alguns românticos, não se compara, em se tratando de um "ambiente propício" (diria Drummond) a grandes realizações humanas, a fugidios vislumbres da velha Europa, cujas vistas contêm, por contraste, espessas camadas daquilo que Nabuco chamará de "fundo histórico". Assim se explica o menosprezo dos grandes panoramas da natureza americana ante a profundidade que a História confere a certos cantos de Paris, a certas curvas de uma estrada da Itália meridional:

Eu sei bem, para não sair do Rio de Janeiro, que não há nada mais encantador à vista do que, ao acaso, a escolha seria impossível, os parques de S. Clemente, o caminho que margeia o aqueduto de Paineiras na direção da Tijuca, a ponta de S. João, com o Pão de Açúcar, vista do Flamengo ao cair do sol. Mas tudo isto é ainda, por assim dizer, um trecho do planeta de que a humanidade não tomou posse; é como um Paraíso Terrestre antes das primeiras lágrimas do homem, uma espécie de jardim infantil (Ibidem:70-1)

De fato, reconhece o autobiógrafo, o Novo Mundo pode ser "encantador à vista", mas se trata de encantamento primário, agrado momentâneo aos olhos. O Velho Mundo oferece encantos que recompensam um olhar enriquecido por uma determinada formação e podem, portanto, reconhecer na paisagem os sedimentos produzidos pela cultura. Se, ao contemplar a Praia do Flamengo, Joaquim Nabuco via o Pão de Açúcar e algumas opulentas residências construídas havia não muito tempo, no Cais do Sena, uma caminhada de alguns minutos lhe permitiria visitar, por exemplo, a Notre Dame de Paris, exemplar notável da arquitetura gótica do baixo medievo, cenário da coroação de Napoleão e do famoso romance de Victor Hugo, a Conciergerie, prisão onde Maria 
Antonieta aguardara o julgamento que lhe resultaria fatal, além, evidentemente, do Louvre, palácio onde muitos reis franceses viveram e reinaram, convertido posteriormente em museu de visita obrigatória aos admiradores da grande arte. Por comparação, a paisagem carioca, ainda que bela, causava ao observador cônscio de determinada concepção do potencial humano e das formas de sua realização a impressão de um angustiante vazio.

\section{III.}

O pensamento europeu que formava a "imaginação" de Joaquim Nabuco vinha passando, em sua fase moderna, por aquilo que Hannah Arendt chamou de "alienação do mundo". Trata-se de um fenômeno complexo, ao qual remeto aqui sem o devido alento para poder analisar o mal de Nabuco de um ponto de vista mais amplo. Uma teoria do conhecimento de orientação aristotélica, predominante na cristandade latina no início do Renascimento, compreendia que a verdade da natureza seria, grosso modo, acessível pela observação. Com o advento da Reforma, a invenção do telescópio e o descobrimento da América, um abalo estrutural desestabilizou esse axioma: o mundo, cujos limites estavam sujeitos até então somente a vagas especulações, era comprovadamente finito; a Igreja, que até então se podia confundir com a sociedade mesma, pôde ser contestada, circunscrita à hierarquia clerical, enquanto a religiosidade se veria paulatinamente reduzida à esfera privada; finalmente, com o uso de um instrumento feito pelo homem (o telescópio) era possível provar que, ao contrário das aparências, é a Terra que orbita o Sol. Nesse novo contexto, seria altamente questionável fundamentar a busca pela verdade na pura observação. A verdade do mundo, até então tida como auto-evidente, não passara de ilusão. Um desmascaramento de tais proporções lançou a humanidade num movimento introspectivo, concorrendo para um distanciamento da natureza. A ideia de que encontramos o conhecimento ao mergulharmos dentro de nós mesmos, hoje bastante difundida, aparece articulada pela primeira vez em meio a essa torrente, com o Cogito de Descartes (ARENDT, 1987: 260-292). Como consequência, “a época moderna, com sua crescente alienação do mundo, conduziu a uma situação em que o homem, onde quer que vá, encontra apenas a si mesmo" (ARENDT, 2014: 125). Não há dúvida de que tal processo, aqui descrito apenas muito esquematicamente, foi algo momentoso para os europeus que o testemunharam. Para aqueles que se educaram segundo a tradição 
moderna, fora do ambiente que a propiciou, essa alienação teria ainda outros efeitos desestabilizantes.

Um jovem brasileiro como o Joaquim Nabuco de vinte e poucos anos, pertencente à elite letrada, educado segundo ideias importadas do outro lado do oceano, sente em sua terra natal uma angustiante falta: olha ao seu redor à procura de "vistas" que dialoguem com sua "imaginação europeia" (aqui se trata em certa medida, como sugere a ideia de alienação do mundo, de uma procura de si mesmo), mas só encontra uma natureza exuberante cuja beleza "inculta" denuncia, para seu desespero, que ele está num "trecho do planeta de que a humanidade não tomou posse", um “jardim infantil". Traz a bagagem cultural do homem alienado da natureza e procura os rastros de seus ancestrais, encontrando somente um éden extemporâneo. Sente-se como um Adão que viajou no tempo ("é como um Paraíso Terrestre antes das primeiras lágrimas do homem"), cujo destino é pior do que aquele do Adão do Gênesis: a queda aconteceu há milênios, ele sabe de outros homens que vivem, a um oceano de distância, num mundo que ergueram por sua engenhosidade (algo possível somente após o pecado original). É por saber disso que ele não consegue pretender ser o primeiro homem e usufruir dos prazeres do paraíso. A sensação que daí resulta é de um estranho e solitário exílio mental:

[O] Novo Mundo para tudo o que é imaginação estética ou histórica é uma verdadeira solidão, em que aquele espírito se sente tão longe das suas reminiscências, das suas associações de ideias, como se o passado todo da raça humana se lhe tivesse apagado da lembrança e ele devesse balbuciar de novo, soletrar outra vez, como criança, tudo o que aprendeu sobre o céu da Ática... (NABUCO, 2013 [1900]: 71).

O éden que o navegador europeu descobrira na América séculos antes se torna como que uma colônia penal para seu sucessor, que será talvez mais Sísifo que Adão. Terá de refazer, sob inclemente sol tropical, tudo que já vinha sendo feito há milênios sob o céu da Ática, do Lácio, da Île-de-France. Daí não se conclua que um tal vazio se preencherá tão só pela via de uma imersão no "ambiente propício" do qual sente falta lembremos que o jovem Drummond, epígono relutante do jovem Nabuco, não desejava simplesmente ir viver na França, mas ter nascido lá. Chegando à Europa com a qual sonha acordado ao contemplar as praias cariocas, ocorre na alma do jovem brasileiro narrado em Minha formação uma admirável reviravolta: aquela paisagem que atiçava a 
imaginação, plena de sedimento histórico, já há muito ansiosamente antecipada, é de uma novidade tal que não se deixa oferecer aos sentidos em sua completude. O jovem, que imaginara sua chegada ao Velho Mundo como um retorno a suas supostas origens, depara-se outra vez com a sensação de desterro e extemporaneidade. Os termos usados por Nabuco nos facilitam a análise por sua perfeita simetria, pois a reversão se afigura de maneira que o "retorno" à Europa é um retorno àquela mesma condição do homem cercado por um desconhecido exuberante: "No meio do luxo dos teatros, da moda, da política, somos sempre squatters, como se estivéssemos ainda derribando a mata virgem" (2012: 71). ${ }^{1}$ Paris é uma selva.

\section{IV.}

Ricardo Benzaquen de Araújo propõe uma compreensão nuançada do dilema do jovem Nabuco, ressaltando que sua exposição inicial como "a mais terrível das instabilidades" está ligada a uma melancolia juvenil errática do "homem das multidões" de Edgar Allan Poe (ARAÚJO, 2006: 8) vivenciada na primeira viagem à Europa, durante a qual o narrador tem uma subjetividade "horizontal" incapaz da plena fruição das realizações estéticas do Ocidente, que se lhe afiguram como uma "infernal sucessão de impactos"- tanto mais infernal quanto maior é o abismo entre o Brasil edênico e inculto, ao qual está acostumado, e a Europa. Tal instabilidade obsta igualmente o desenvolvimento do juízo político - que, para Nabuco, é tributário do juízo estético (ARAÚJO: 2006: 7-8)². A estada prolongada em Londres, por contraste, oferece ao narrador o desenvolvimento "vertical" (Ibidem: 12) por meio da tranquilidade idílica de uma "Arcádia moderna" (p. 10), menos confortável e espetacular do que Paris, mas

\footnotetext{
${ }^{1}$ A impossibilidade de escapar à selva apresenta ainda uma interessante simetria com a tomada de consciência da parte dos europeus, já num momento posterior, de que a colonização e a expansão do capitalismo estavam em vias de interditar qualquer possibilidade de contato com uma alteridade real ou com uma natureza "inculta". Veja-se, por exemplo, a primeira parte de Tristes trópicos (LÉVI-STRAUSS, 1996 [1955]: 15-45).

${ }^{2}$ Em diversas passagens de Minha formação, Nabuco deixa claro que a estética é o fundamento de toda a sua percepção do mundo. Eis duas particularmente pungentes: "Cada um de nós é só o raio estético que há no interior do seu pensamento, e, enquanto não se conhece a natureza desse raio, não se tem ideia do que o homem realmente é." (p. 72); "eu trocara em Paris e na Itália a ambição política pela literária, crítica, isto é, com uma espessa camada europeia na imaginação, camada impermeável à política local, a ideias, preconceitos e paixões de partido, isoladora de tudo que em política não pertencesse à estética, portanto também do republicanismo - porque a minha estética política tinha começado a tornar-se exclusivamente monárquica" (p.99). Maria Alice Rezende de Carvalho observa que, em Nabuco, "a literatura e a política caminhavam juntas, ou melhor, eram tidas como partes indissociáveis da imaginação estética aplicada à produção de uma grande obra, fosse ela o texto, a sua vida pública ou a nação" (CARVALHO, 2001: 223).
} 
acolhedora em sua "solidez eterna, egipcíaca" (Ibidem: 10). Araújo, surpreendentemente, deixa fora de sua análise o momento no livro em que a quietude sólida permite a fixação do espírito, que se dará, curiosamente, na França. Trata-se da passagem sobre sua estada em Fontainebleau, onde

não é o castelo e a floresta só por si o que me prende; é que volto da Inglaterra, tendo pela primeira vez falado inglês com todo o mundo, fascinado por Londres, tocado de um começo de anglomania, que foi a doença da sociedade em França, e, portanto, até isso, acusa a construção francesa do meu espírito, e Fontanebleau, com o repouso dos seus jardins simétricos, a frescura de suas águas e das suas sombras, a tranquilidade do seu silêncio, era o mais admirável retiro que eu podia querer nesse mês da minha vida, que posso chamar do mês de Thackeray (NABUCO, 2013 [1900]: 75).

A passagem mais corrobora do que contradiz Araújo, visto que as leituras de Fontainebleau são inglesas e que a estada é sobretudo uma pausa do frenesi da viagem, incluindo a passagem por Londres; contudo, é em meio às recordações recentes de lá que a paz é encontrada. Fontainebleau é o cenário onde o Nabuco das multidões adquire uma maturidade incipiente, gestada em meio à leitura de Thackeray e outros ingleses. A "anglomania" aparece como tributária da "construção francesa do espírito": era, afinal, uma moda francesa. Antes que uma contradição, a passagem apresenta uma evidência de um traço importante da subjetividade do protagonista: o primado do estético como eixo central de compreensão da vida.

Não fica descartada pela análise de Araújo a possibilidade de persistência da dualidade transatlântica na maturidade de Nabuco, que publica as linhas aqui comentadas aos cinquenta anos, escrevendo do alto de uma sólida trajetória pública, sobre sua “instabilidade". Maria Alice Rezende de Carvalho nota que "a superação da dualidade (...) jamais se verificaria plenamente, sendo essa, aliás, uma das contingências da vida intelectual nas sociedades retardatárias, que obriga a viver, como imaginação, aquilo que, nos países centrais, já se impõe como sociologia” (CARVALHO, 2001: 229). Carvalho vê nas meditações de Nabuco sobre seu dilema transatlântico um "esboço de sociologia da intelectualidade periférica" (2001: 228). Evaldo Cabral de Mello, em constatação semelhante, identifica ali a articulação do "dilema do mazombo", o descendente de europeus na América com um pé de cada lado do oceano (MELLO, 2002: 235). Carvalho 
nota sobre Minha formação que "parte considerável da coletânea autobiográfica dedicase à confirmação dos efeitos que o legado civilizacional do Ocidente produziu sobre ele [Nabuco]" (CARVALHO, 2001: 227). O valor sociológico da sua reflexão, que é uma interpretação de sua classe, fica evidente quando notamos que o dilema ainda assombrará Carlos Drummond de Andrade duas décadas depois, e, ainda hoje, podemos observar entre alguns brasileiros uma persistente atração pelo cais do Sena ou, como provoca Evaldo Cabral de Mello, por Miami (MELLO, 2002: 236).

Num trabalho mais recente, Luiza Larangeira da Silva Mello (2012) identifica em Minha formação a produção de uma "sensibilidade cosmopolita" a partir da ligação a valores europeus à luz da emergente individualização da vida que acompanhou o advento da modernidade industrial. Se, na Europa, a busca pela singularização resultaria na busca de uma experiência do "autêntico" mediante a incorporação de culturas "antigas" ou "tradicionais" fora de uma Europa onde tal experiência era reprimida pelo apagamento da subjetividade em meio à multidão, na América, a busca pela autenticidade se daria na "mesma direção", mas no "sentido contrário": o autêntico se encontraria na Europa, na medida em que ali a civilização havia logrado progredir conservando virtudes do passado, harmonizando modernidade e tradição. Esse progresso orientado por valores tradicionais revelava, na visão de intelectuais americanos que desenvolveram uma sensibilidade cosmopolita ao atravessar o Atlântico, como Joaquim Nabuco e Henry James, a universalidade de certos traços europeus. Para o primeiro, a Europa atraía por sua contraposição ao caráter incivil, patrimonial e escravocrata do Brasil; ao passo que, para o segundo, ela representava um local onde a modernidade tinha um lastro histórico, humanista, ao contrário de sua manifestação nos Estados Unidos, que, nas palavras atribuídas a Georges Clemenceau, pareciam ter passado da barbárie à decadência sem ter conhecido o estágio intermediário da civilização (MELLO, 2012: 74-75). ${ }^{3}$

Os Estados Unidos das páginas de Minha Formação, em evidente contraste com aqueles que aparecerão nos escritos do Nabuco embaixador (acentuadamente americanófilos), são bem diferentes da Arcádia anglo-saxã de Londres. Aqui, os anos de adido de legação oferecem um aprendizado das falhas do presidencialismo americano, evidenciadas pela corrupção generalizada e pela polarização partidária, ilustradas pelo caótico cenário pós-eleitoral de 1877 (NABUCO, 2013[1900]: 150). A “atmosfera moral” da nação era “viciada" (p. 152), a "lei de $\operatorname{Lynch}^{4}$ [...] lhe está no sangue" e, aqui o narrador

\footnotetext{
${ }^{3}$ A alusão ao estadista francês não é feita pela autora, mas me pareceu ilustrativa para o tema.

${ }^{4}$ No português dos nossos dias, linchamento.
} 
vê o pecado maior, há "uma população de 7 milhões, toda a raça de cor, para a qual a igualdade civil, a proteção da lei, os direitos constitucionais são contínuas e perigosas ciladas" (2012: 122). Não tão distante é o retrato da França, marcada pela instabilidade institucional, representada como a "casa de Ulisses" com vários "pretendentes" (2012: 141), "um país e um país livre, mas sem espírito de liberdade arraigado, sujeito sempre às crises das revoluções e da glória” (2012: 122). A ojeriza à política americana é sobretudo uma ojeriza à política exaltada, contraposta à serenidade e parcimônia com que são conduzidos os negócios públicos na Inglaterra. Vale notar que o entendimento dos Estados Unidos como um sucedâneo abrutalhado da Inglaterra parece advir sobretudo de uma certa teleologia da história, de cunho racialista, tomada emprestada de Herbert Spencer, que é citado apresentando a sociedade americana como função da raça anglosaxã no Novo Mundo, com grande potencial ainda não desenvolvido (2012: 166), a ser confirmado ou não pelo passar do tempo.

O estranhamento com a política em moldes não-ingleses será ainda manifestado com relação ao Brasil. O narrador de Minha formação, cuja "imaginação europeia" é contraposta a um "sentimento brasileiro", será marcado por uma percepção de nãopertencimento à maneira de fazer política do Brasil bragantino, ilustrada sinteticamente neste trecho:

Com efeito, quando entro para a Câmara, estou tão inteiramente sob a influência do liberalismo inglês, como se militasse às ordens de Gladstone; esse é em substância o resultado de minha educação política: sou um liberal inglês — com afinidades radicais, mas com aderências whigs — no Parlamento brasileiro (2012:185).

O narrador é um "liberal inglês" - e não brasileiro, mantendo distância do próprio partido - "com afinidades radicais e aderências whigs" - prefere usar o vocabulário político inglês a encontrar análogos brasileiros. Essa alteridade, que é dupla, se remetermos a sua caracterização dos homens do novo mundo na Europa como "squatters" “derribando a mata virgem" (NABUCO, 2012 [1900]: 70) reafirma o dilema do mazombo. A excentricidade, a dualidade, a constante confrontação entre um estado d'alma e as contingências do real são marcas da construção do sujeito em Minha Formação - e aqui parece haver uma persistente correspondência com outros textos e momentos da vida de Joaquim Nabuco. Voltando-se esta proposição para o trabalho de 
Araújo (2006), chegamos a uma solução que mantém a dupla alteridade: a instabilidade juvenil é pacificada no espírito através da construção assertiva, vertical, de uma subjetividade transatlântica. Nabuco trilha um caminho próprio: seguirá como um liberal inglês no parlamento brasileiro e como um squatter na Europa.

\section{V.}

Outro componente do europeísmo de Nabuco pode ser observado a partir de uma confissão feita no livro, cuja sinceridade parecerá mais provável após uma consulta ao restante de sua obra. Nabuco acreditava ter o francês como primeira língua, ao menos na escrita:

[A]gora, vinha a necessidade de produzir, de criar, e dava-se um fato singular, resultado desses anos de leituras francesas: eu lia muito pouco o português, ainda não começara a ler o inglês e desaprendera o alemão [...]. O resultado foi que me senti solicitado, coagido pela espontaneidade própria do pensamento, a escrever em francês (NABUCO, 2013[1900]: 88).

Nabuco remete aqui a suas primeiras incursões na escrita literária, feitas em língua francesa: escreveu Le droit au meurtre, um panfleto cujo objetivo parece ter sido impressionar Ernest Renan, Amour et Dieu, livro de poemas que ele próprio admitiria depois ser medíocre (2012: 93-100), L’Option, drama em cinco atos sobre uma família dividida pela guerra franco-prussiana ${ }^{5}$. Mais tarde, escreveria Foi Voulue, volume autobiográfico redigido em 1893 sobre sua conversão tardia ao catolicismo, e Pensées Détachées et Souvenirs, coleção de aforismos onde o autor se aventura, sem boa acolhida da crítica francesa, na filosofia. Logo após o trecho citado acima, Nabuco continua:

Um brilhante frequientador da Revista Brasileira, que possui entre outras qualidades talvez a mais preciosa de todas, uma boa quantidade do fluido simpático, admira-se dessa minha afinidade francesa; com efeito, não revelo nenhum segredo, dizendo que insensivelmente a minha frase é uma tradução

\footnotetext{
${ }^{5}$ É revelador que Nabuco, que escreveu a peça durante o período em que foi adido de legação nos Estados Unidos, teça um drama sobre um dilema entre duas pátrias: Clotilde, a heroína, tem de escolher entre um pretendente francês e um prussiano.
} 
livre, e que nada seria mais fácil do que vertê-la outra vez para o francês do qual ela procede (NABUCO, 2012 [1900]: 88).

Nabuco nos indica acima que cada linha que escreve em português é uma tradução livre de um "original” francês, revelação que certamente contribuiu para a má vontade com que modernistas o leram. Não se deve desprezar, contudo, seus escritos em língua francesa como mera manifestação de uma recusa recalcada da língua portuguesa, nem presumir que superestimava seu domínio do francês e que, portanto, sua prosa só alcançaria brilho no português. Nabuco foi um grande admirador de Camões, tendo discursado na solenidade de tricentenário do poeta no Rio de Janeiro, quando foi lançada, na presença do Imperador, a pedra fundamental do Real Gabinete Português de Leitura ${ }^{6}$. Mais tarde, discursaria exaltando Camões como embaixador do Brasil nos Estados Unidos em universidades americanas a fim de difundir os Lusíadas e a língua portuguesa num país onde se imaginava que os brasileiros falavam espanhol. Atestado incontestável da desenvoltura do francês de Nabuco é um fato não muito conhecido. "Massangana", o capítulo de Minha formação que a fortuna crítica consagrou como antológico (mesmo quando lamentavelmente incompreendido), é a versão para o português, com algumas modificações marginais e a omissão de um parágrafo, de um texto em francês escrito em 1893 à guisa de capítulo de abertura do livro Foi voulue, autobiografia de teor mais religioso publicada postumamente (NABUCO, 1971[1893]). Massangana viria a público em francês durante a vida de Nabuco como o penúltimo capítulo de Pensées Détachées, publicado em 1906 pela Hachette, importante editora parisiense. Machado de Assis elogiou efusivamente o livro em carta a Nabuco, destacando a qualidade da "versão" de Massangana (Apud ARANHA, 1923: 166-167) - que ele não sabia ser, na verdade, o original. Na França, o crítico Émile Faguet, membro da Academia Francesa, tomou Nabuco por pseudônimo de um escritor francês e, se não fez elogios ao conteúdo da obra, elogia sua forma:

Joaquim [sic] Nabuco — évidemment un pseudonyme — est un homme qui doit approcher de la soixantaine, qui a eu une très forte éducation francoanglaise, qui a été fortement ému pour un temps par Chateaubriand, par Shelley et par Renan, pour toujours par la Bible; qui n'ignore, du reste, ni la

\footnotetext{
${ }^{6} \mathrm{O}$ fato de Nabuco, um brasileiro, ter sido escolhido para discursar na celebração do poeta português, em meio a um momento de tensão entre a população carioca e a comunidade de imigrantes lusos foi motivo de polêmica, cf. VENANCIO, 2013.
} 
philosophie allemande ni Auguste Comte, qui a passé une partie de sa vie probablement dans des fonctions diplomatiques au Brésil, qui a moins écrit que lu et moins lu que réfléchi, qui s'est fait ainsi une très forte originalité d'esprit, où il entre un peu de bizarrerie, et qui aime à écrire des "pensées détachées", à là manière habituelle de Nietzsche, plutôt que des livres composés (FAGUET, 1907: 194).

Faguet vê nas Pensées uns poucos espasmos de originalidade e genialidade; no mais das vezes, porém, encontra ideias batidas reelaboradas com algum refino. Sua crítica termina reconhecendo que "esta esponja otimista [Faguet alude em tom de deboche a um trecho do livro em que Nabuco se compara a uma esponja] tem, ao menos, uma voz muito bem articulada" (1907: 195) ${ }^{7}$. A afinidade com a língua francesa parece ter contribuído para a qualidade de seu texto em português: a prosa de Nabuco é muitas vezes mais fluida do que aquela de alguns de seus contemporâneos, adeptos de uma sintaxe rebuscada, onde abundam as inversões. É o que nota José Guilherme Merquior (1977) quando avalia que o estilo de Nabuco é "moderno", "leve e solto", "muito mais próximo da corredia sintaxe francesa do que das complexas construções lógicas do português clássico" e que "essa relativa francização da língua escrita pela frase nabuquiana é o pendant brasileiro do que se consumava, em Portugal, na mesma época, na obra de Eça de Queirós: as inflexões galicistas eram, na verdade, táticas de modernização do idioma culto" (1977: 188).

\section{VI.}

O penúltimo capítulo de Minha formação é dedicado ao Barão de Tautphoeus, preceptor e professor do Colégio Pedro II. Seu retrato parece oferecer um contraponto ao dilema transatlântico ou, mais precisamente, sua reformulação a partir de um ponto de vista simetricamente oposto, permitindo a investigação de alguns matizes que de outra maneira permaneceriam ignorados. O professor aparece primeiro como uma encarnação da tradição clássica:

Certamente ele realizava para mim o tipo de Sócrates. Se não trazia a máscara de Sileno emprestada ao grande ateniense, mesmo fisicamente, sobretudo para a velhice, ele tinha muitos dos traços socráticos: a coragem fria, a calma imperturbável, a resistência à fadiga, o gosto da palestra, da conversação

\footnotetext{
7 “Ce spongiaire optimiste a, au moins, une voix très bien articulée".
} 
intelectual, da companhia dos moços, a completa abstração de si, a modéstia, a alegria de viver como espectador do universo, cedendo sempre todavia aos outros o melhor lugar, o forte espiritualismo, a indiferença pelo ridículo, o respeito da ordem social, quem quer que a encarnasse (NABUCO, 2013[1900]: 241).

Tautphoeus é o espelho do mazombo, "alheio ao mundo exterior" (2012: 241), dotado de inesgotável erudição, "falava de um modo uniforme, sem ênfase, sem colorido, sem expressão mesmo, mas era um jorrar sem fim de ciência" (2012: p. 242), era "esse respeitador por sistema da ordem hierárquica e da pragmática social, que nunca levou a mal que os poderes de um dia se considerassem seus superiores, que os afidalgados da véspera olhassem com desdém para o seu título hereditário". (2012: 242). ). O velho alemão é um nobre anônimo, que não ostenta a fidalguia, como um tesouro inacessível ao esnobismo provinciano da nobreza tropical sem berço, um anti-rastaquera. Sua dignidade se manifesta pela indiferença à adulação; sua erudição é um fim em si mesmo, seus ensinamentos são estritamente pedagógicos e desinteressados. "Bebeu a água do Carioca com o mesmo espírito de conformação com que teria bebido a água de Letes..." (2012: 243).

Por mais fora de lugar que Tautphoeus pareça num primeiro momento, uma maior atenção à arquitetura da narrativa de Minha formação permite perceber ele cumpre um papel central na função do livro como elogio das tradições imperiais que a proclamação da República havia posto a perigo. Tautphoeus personifica o Brasil monárquico, com suas instituições sustentadas em sabedoria remontante a tempos supostamente imemoriais, transplantada nos trópicos: nas palavras de Nabuco em Um estadista do Império, a "planta exótica” (NABUCO, 1975 [1897]: 71). O ocaso do Império será também o do professor:

Desse simples funcionário do Estado, que não tinha de seu senão seu modesto ordenado de cada dia, e além disso, estrangeiro de origem, partiu talvez o único grito de: Viva a Constituição do Império! que se ouviu — tão fraca era já a voz — em 15 de novembro ao desfilar [sic] das tropas do general Deodoro pela rua do Ouvidor (NABUCO, 2013[1900]: 244).

A tragédia de Tautphoeus, a de ter sobrevivido ao seu tempo, é também a do Nabuco pós-15 de novembro - embora para este isso tenha acontecido numa idade menos avançada -, e este creditará àquele a capacidade de juízo histórico que é exercitada ao 
longo das páginas de Minha formação e de Um Estadista do Império: "diante dele, pensando nele, me habituei a considerar o juízo do historiador como o juízo definitivo, o que importa, final, e por isso aquele que [sic] se deve desde logo visar", "O juízo da multidão que hoje nos eleva ou nos deprime, esse representa apenas a poeira da estrada" (2012: 245). A serenidade de Tautphoeus dá ao narrador, voz de um Nabuco ele próprio incerto de seu legado, a certeza de que a história o absolverá ${ }^{8}$. Os últimos dias do mestre oferecem nítido contraste com a juventude errática do narrador, que não trocaria as belezas do Novo mundo por "um pedaço do cais do Sena" (2012: 70): o velho contentase na contemplação da natureza inculta, desprovida do sedimento histórico:

A nossa vivenda de Paquetá agradava-lhe por lhe dar, com o silêncio e isolamento que cercava a biblioteca, a escolha, à vontade, do mar, do campo e da montanha: as praias extensas, a floresta acessível, a planície atapetada, se lhe agradava passear; a água serena, o mar fechado à vista, como um lago suíço, se queria tomar o nosso barco e mandar o Mudo, o nosso saudoso remador, abrir a vala para os pequenos ilhotes de onde se avistam de um extremo os Órgãos de Teresópolis, e no outro a serrania da cidade... (NABUCO, 2012 [1900]: 247-8).

A paisagem reaparece aqui, não como angustiante lembrete da falta de lastro histórico, mas como fonte de paz. O narrador parece projetar nos velhos sentimentos que podem ser mais do autor, ao escrever, que do barão: "via-se o cansaço de ter pensado tanto e o involuntário tributo à dúvida: se teria bem aproveitado o tempo, ou se teria vivido em vão" (2012: 248). Há, porém, algo mais. O fim de Tautphoeus como tragédia do império pode também ser interpretado como a aceitação de Nabuco da necessidade de se reconciliar com o que percebe como o próprio fracasso. $\mathrm{O}$ dilema imposto na juventude se encontra aqui contrastado pela tragédia do velho que entendera o império melhor do

\footnotetext{
${ }^{8}$ Georges Gusdorf oferece uma boa ilustração dessa dimensão como típica do gênero autobiográfico: “The autobiography that is thus devoted exclusively to the defence and glorification of a man, a career, a political cause, or a skillful strategy presents no problems: it is limited almost entirely to the public sector of existence. It provides an interesting and interested testimony that the historian must gather together and criticize along with other testimonies. It is official facts that carry weight here, and intentions are judged by their performance. One should not take the narrator's word for it, but should consider his version of the facts as one contribution to his own biography. Private motives, the obverse of history, balance and complete their opposite, the objective course of events. But for public men it is the exterior aspect that dominates: they tell their stories from the perspective of their time, so that their methodological problems are no different from those of the ordinary writing of history. The historian is well aware that memoirs are always, to a certain degree, a revenge on history" (1980: 36).
} 
que seus cidadãos de jure. Se lermos a narração do fim de Tautphoeus atentando para a intransigência com que Nabuco defende seus princípios monárquicos em páginas anteriores, a morte do mestre parece abrir ao protagonista um novo horizonte: será possível seguir em frente guardando a tradição como um norte moral e afetivo aceitando, por outro lado, a necessidade de se adaptar à novas circunstâncias. O que nas páginas anteriores se vinha carregando como um peso se torna roteiro para uma segunda vida.

VII.

Em dois momentos de Minha formação encontraremos uma atração pelo Brasil, inversa àquela sentida pela Europa, talvez surpreendente à luz da leitura mais convencional que se costuma fazer do texto. A hipérbole com que Nabuco compara a paisagem brasileira desfavoravelmente à europeia, somada aos muitos capítulos em que exalta as tradições francesas (artísticas) e inglesas (políticas), por certo ofuscam outras passagens, que nem por isso devem passar ignoradas. A primeira que examinaremos está inserida em meio a descrições entusiasmadas dos encantos da alta culinária, dos quais que teve a oportunidade de provar durante suas estadas na França e na Inglaterra:

Há, entretanto, poesia real, verdadeira, no alimento são, natural, pátrio; há sentimento, tradição, culto de família, religião, no prato doméstico, na fruta ou no vinho do país. A nós, do norte do Brasil, criados em engenhos de cana, o aroma que rescende das grandes caldeiras de mel nos embriaga toda a vida com a atmosfera da infância (NABUCO, 2012: 119).

A inserção da memória da infância em Pernambuco na em meio a recordações do período em que frequentou opulentos jantares londrinos (a passagem pertence ao capítulo intitulado Grosvenor Gardens, endereço da Legação brasileira em Londres) dá a impressão de evocar algum momento em que, durante uma refeição cheia de pompa e circunstância, o cheiro de mel de algum prato o conduzisse furtivamente à atmosfera do engenho de sua meninice. Adiante, em Massangana (capítulo cujo título é o nome do engenho), a memória involuntária trazida à tona por um acidente sensorial reaparece:

Durante o dia, pelos grandes calores, dormia-se a sesta, respirando o aroma, espalhado por toda a parte, das grandes tachas em que cozia o mel. (...) Os 
filhos de pescadores sentirão sempre debaixo dos pés o roçar das areias da praia e ouvirão o ruído da vaga. Eu por vezes acredito pisar a espessa camada de canas que cercava o engenho e escuto o rangido longínquo dos grandes carros de bois... (2012: 188).

A referência que vem à mente com essas passagens é o célebre trecho de Em busca do tempo perdido no qual o narrador rememora acidentalmente todo o universo de sua infância, com uma riqueza de detalhes que de outra maneira lhe seriam inacessíveis, atiçado pelo inalar do aroma de madeleines mergulhadas numa infusão de ervas. Apesar de anacrônica (é improvável que Nabuco tenha lido qualquer obra de Proust), a comparação entre Nabuco e Proust, já foi feita algumas vezes por comentaristas brasileiros $^{9}$. Mesmo que não tenha lido Proust, Nabuco dele se aproxima ao invocar o aroma como catalisador de uma memória involuntária que presentifica aspectos do passado inacessíveis à rememoração intencional. É essa sensação que ativa, aqui, um movimento contrário à “atração do mundo" e à saudade do cais do Sena. Mesmo imerso numa atmosfera de pompa e requinte, o cheiro de mel e os ecos dos carros de boi jamais permitirão que Nabuco se esqueça do engenho onde foi criado, corroborando sua formulação anterior da pátria como "sentimento" em oposição ao mundo (Europa) como “imaginação".

O dilema transatlântico de Nabuco, já notamos, não se atém à juventude ou a uma dimensão meramente retórica. Em 1899, Nabuco voltava à diplomacia e partia para a Europa, onde permaneceria até 1905, quando seria nomeado embaixador em Washington, permanecendo nos Estados Unidos até sua morte, em 1910. Sua última estada no Brasil se deu em 1906, quando presidiu o III Congresso pan-americano, realizado no Rio de Janeiro. Passaria ainda por São Paulo, Minas Gerais e pelo Recife. Uma carta ao Barão do Rio Branco datada de 17 de agosto de 1907 oferece um interessante contraponto à passagem na qual o autor declara que não trocaria as belezas todas do novo mundo por um ou outro pedaço da Europa. Nabuco, em licença médica na Alemanha, escreve, nostálgico:

\footnotetext{
${ }^{9} \mathrm{Na}$ biografia de Angela Alonso, lemos que "o engenho de fogo morto, o Massangano do Quimquim [apelido infantil de Nabuco] ressurgiu da rememoração com contornos proustianos e femininos. Jaguaribe (1994:29) nota que a paisagem da infância ressurge em Massangana "mediante a rememoração ao estilo proustiano" (2007 :290-1). Em seu verbete sobre Nabuco no Dicionário histórico-biográfico do CPDOCFGV, Rubens Ricupero caracteriza o próprio Nabuco como dotado de "finura proustiana" ao compreender que a monarquia, depois da Revolta da Armada, era uma causa perdida (RICUPERO, s.d.).
} 
Meu querido amigo,

Estes dias de Reno me têm dado a antiga vibração. Nada faz tanto bem como uma viagem quando o espírito se sente inerte, e eu me estava sentindo assim desde que me proibiram o trabalho intensivo. Sem as antigas ilusões pessoais e sem muito trabalho vêm naturalmente as preocupações, as saudades, a longa contemplação inútil do declínio, e finalmente se produz não a melancolia, mas a apatia, que é preciso combater até o fim quando se é um otimista como eu. Para isso não há como o contato com fontes de inspiração, uma das quais é a história e a lenda, na falta de outras que o Sr. tem aí ao seu lado, entre as quais conto a companhia de espíritos possuidores, como o de alguns que o cercam, do dom de agitar-nos e de tornar a vida para nós uma festa. Estou agora às voltas com as lendas dos castelos e com a história do Reno. Ele é a verdadeira Via Sacra Alemã. Mas mesmo sem a história a paisagem já bastaria. A vista que tive ontem do terraço de Drachenfels é somente comparável pela impressão que causa à de Taormina. São dessas vistas das quais o mais belo tipo é a nossa Vista Chinesa, ou a do Corcovado (NABUCO, 1907: s.p.).

Mesmo ressaltando o elemento histórico da paisagem do Reno, que é o que justifica em Minha formação a suposta superioridade da paisagem europeia sobre a brasileira, como vimos acima, um Nabuco adoentado, saudoso do Brasil, relembra uma Vista Chinesa e um Corcovado mais belos do que Drachenfels ou Taormina (outra vez aparece a memória involuntária: num passeio pela Alemanha, Nabuco tenta admirar e absorver uma vista e é tragado pela lembrança de vistas cariocas). É interessante notar que a Vista Chinesa não era uma lembrança da infância ou da adolescência de Nabuco. O mirante, cujo coreto tem o aspecto de um pagode chinês, foi inaugurado em 1903. Nabuco só poderia tê-lo visitado, portanto, durante sua estada no Rio em 1906. Note-se, ainda, que se trata da mais "primitivista" entre as construções da belle époque carioca: um mirante destinado à admiração da natureza, inserido no registro simbólico das narrativas de viajantes que retrataram um Brasil edênico e exótico. Um extremo oposto do "cais do Sena" que habitava os sonhos do jovem Nabuco. Daquilo mesmo, porém, o Nabuco embaixador sentia saudade. O mal de Nabuco, parece, não se deixou abandonar na praia do Flamengo. 
VIII.

Tentei matizar ao longo deste estudo a noção convencional, devida em alguma medida às boutades de Mário de Andrade, de que o "mal de Nabuco" seria tão somente um desejo escapista de ir viver na Europa ou, não se podendo fazê-lo, um afã de imitar modelos europeus. Isto já não seria difícil de realizar lançando mão da própria passagem sobre o cais do Sena - afinal, já ali há uma instabilidade constitutiva da subjetividade, e não uma mera "atração" de mão única pela Europa. Outras passagens de Minha formação e de outros escritos da mesma época pelo mesmo autor acima analisadas são testemunhos adicionais da complexidade do problema e, assim entendo, do potencial da remissão à instabilidade nabuquiana para a compreensão de problemas que estão na ordem do dia da cena cultural brasileira. Isto, porém, não é tudo. Se introduzi o problema com Mário, o que já foi feito por Ricardo Benzaquen de Araújo (2004), Silviano Santiago (2006) e Ítalo Moriconi (2001), é porque gostaria de concluir com uma hipótese que nos leva de volta ao autor paulista.

O "mal de Nabuco" como descoberto por Mário de Andrade, suspeito, padece de uma descrição insuficiente. Creio existir por trás da instabilidade transatlântica um fundo mais amplo que não diz respeito somente a uma sensibilidade cosmopolita transplantada numa perspectiva periférica, mas às condições reguladoras da representação da realidade. Quando me vali de Hannah Arendt e sua reflexão em torno da "alienação do mundo", procurava exemplificar com um quadro suficientemente sucinto as possibilidades e limites que o pensamento ocidental apresenta para tal representação ${ }^{10}$. A instabilidade nabuquiana é, penso, expressão da reiterada infelicidade ${ }^{11}$ do transplante de formações mentais europeias para este lado do Atlântico, dando lugar a variados sintomas, um dos quais, presente em ambas as Américas, é a figuração do Novo Mundo como jardim do Éden. Note-se, ainda, que essa infelicidade implica uma relação transtornada do sujeito com o binômio natureza-cultura, presença constante na trajetória da subjetivação na

\footnotetext{
${ }^{10}$ Possibilidades e limites articulados, no Ocidente, em formas cuja particularidade a sociologia e a antropologia já se dedicavam a investigar durante a vida de Joaquim Nabuco, como se pode verificar, por exemplo, no trabalho de Durkheim e Mauss (2013 [1902]) sobre o tema nas sociedades então ditas primitivas, mesmo que a perspectiva ali fosse claramente evolucionista. Uma reflexão atual em torno de outros possíveis sistemas representação da realidade e das relações entre o humano e o não-humano, pode ser encontrada nos estudos de Eduardo Viveiros de Castro (entre outros, 2015:33-69) sobre perspectivismo e multinaturalismo.

${ }^{11}$ Infelicidade que não ocorre, como se viu, com Tautphoeus, que poderá gozar de uma relação mais harmônica e plena com a natureza. O problema não está tanto no lugar onde se está, mas no ponto de vista a partir do qual forma da subjetividade.
} 
Europa moderna - com consequências importantes para outras instâncias mais específicas da representação, por exemplo, aquela estruturada em torno do binômio universalparticular. Natureza e cultura não assentam confortavelmente no universo mental periférico, pois são representações que, importadas conjuntamente a uma inter-relação já determinada, não estão amparadas pelo lastro histórico do qual resulta sua função no pensamento europeu - não que ali o binômio também não seja perpassado de tensões. Dito de outra forma, o sujeito periférico tenta pensar natureza e cultura segundo fôrmas que não se conformam àquela na qual ele, para usar a expressão de Nabuco, foi "vazado ao nascer”. A instabilidade não seria, daí segue, o mal em si, mas seu sintoma mais típico num período que teve uma ideia de Brasil hoje dificilmente sustentável.

Enquanto não se efetuam significações próprias dos termos, ou, enquanto não se produzem outros termos, o binômio é sempre abordado de forma oblíqua e dá lugar a representações transtornadas e sintomáticas da realidade. É o que encontramos na instabilidade constitutiva do narrador de Minha formação. Não deveria ser necessário lembrar que a "moléstia" de Nabuco, tomada nesse sentido mais amplo, persiste em nossos dias - ela se vê, aliás, atualizada e mundializada pelos debates em torno da globalização, do multiculturalismo e do possível advento de um Antropoceno. Tampouco diria que alguém no Brasil contemporâneo se veja facilmente contemplado pela explosiva tematização que as páginas de Macunaíma dedicam às relações entre subjetividade, natureza e cultura sem o travo de uma ironia acre, que talvez tenha mesmo presidido a urdidura da obra. Convém perguntar se o tom lúdico e cômico da narração cumpre eficazmente o papel de contrabalançar a miséria geral do périplo do herói pelo país. Ao final de luminoso ensaio sobre o livro, Alfredo Bosi interpreta seu desfecho como um “canto em decrescendo" (1988: 140). O sentido da alternância entre cidade e selva, para Bosi, é de "impasse; e dor pelo impasse" (1988: 139, grifo do autor). Incapaz de “encontra[r] lugar próprio nem na mata nem na metrópole, [Macunaíma] padece em ambos" (p. 139-40); resta-lhe fugir deste mundo e subir aos céus. Vejamos o que Mário tinha a dizer sobre Macunaíma em carta a Álvaro Lins datada de 4 de julho de 1942:

Pouco importa, si muito sorri escrevendo certas páginas do livro: importa mais, pelo menos pra mim mesmo, lembrar que quando o herói desiste dos combates da terra e resolve ir viver "o brilho inútil das estrelas", eu chorei. Tudo, nos capítulos finais, foi escrito numa comoção enorme, numa tristeza, por várias vezes senti os olhos umedecidos, porque eu não queria que fosse 
assim! E até hoje (é o meu livro que nunca pego, não porque ache ruim, mas porque detesto sentimentalmente ele), as duas ou três vezes que reli este final, a mesma comoção, a mesma tristeza, o mesmo desejo amoroso de que não fosse assim, me convulsionaram (Apud BOSI, 1988: 140).

Brilho inútil das estrelas. O leitor descobre ao final de Macunaíma que o herói é a constelação da Ursa Maior. Não pode, portanto, ser visto de boa parte do Brasil, senão parcial e dificilmente. Mais favorável é o ponto de vista oferecido, por exemplo, a partir das redondezas de Atenas ou de Paris.

Ao fim e ao cabo, a obra maior de Mário de Andrade se deixa ler, sem injúria ao autor, como monumento a uma certa moléstia.

\section{Fontes}

ANDRADE, Mário de (2016 [1928]). Macunaíma: o herói sem nenhum caráter. São Paulo: Penguin Companhia das Letras.

ARANHA, José Pereira da Graça (1923). Machado de Assis e Joaquim Nabuco: Commentarios e notas á correspondência entre estes dous escriptores. São Paulo: Monteiro Lobato \& Cia. Editores.

FAGUET, Émile (1907). Histoire, Morale, Philosophie. Annales Politiques et Littéraires. Paris, n. 1266, 29 set.

FROTA, Leila Coelho (Org.) (2003). Carlos \& Mário: correspondência de Carlos Drummond de Andrade e Mário de Andrade. Rio de Janeiro: Bem-te-vi.

NABUCO, Joaquim (1971 [1893]). Foi voulue. Mysterium Fidei. Marselha: Université de Provence.

(1975 [1897]). Um estadista do Império. Rio de Janeiro: Nova Aguilar. (2013 [1900]). Minha formação. São Paulo, Editora 34.

(1907). Carta ao Barão do Rio Branco. Arquivo Histórico do Itamaraty. Arquivo Barão do Rio Branco, cartas de Joaquim Nabuco ao Barão; Lata 832, maço 1.

\section{Referências Bibliográficas}

ALONSO, Ângela (2007). Joaquim Nabuco: Os salões e as ruas. São Paulo: Companhia das Letras.

ARAÚJO, Ricardo Augusto Benzaquen de (2004). Através do espelho: subjetividade em Minha formação, de Joaquim Nabuco. Revista Brasileira de Ciências Sociais, v. 19, n. 56, pp.5-13 out.

ARENDT, Hannah (1987). A condição humana. Rio de Janeiro: Forense Universitária. (2014). Entre o passado e o futuro. São Paulo: Perspectiva.

BOSI, Alfredo (1988). Situação de Macunaíma. In: crítica literária e ideológica. São Paulo: Ática, pp. 127-141. 
CARVALHO, Maria Alice Rezende de (2001). Joaquim Nabuco: Minha formação. In: MOTA, Lourenço Dantas (Org.). Introdução ao Brasil: Um banquete no trópico. São Paulo: Editora SENAC, pp. 167-191.

GUSDORF, Georges (1980). Conditions and limits of autobiography. In: OLNEY, James (Org.). Autobiography: Essays Theoretical and Critical. Princeton, New Jersey: Princeton University Press, pp. 28-48.

JAGUARIBE, Beatriz (1994). Autobiografia e nação: Henry Adams e Joaquim Nabuco. In: GIUCCI, Guillermo \& DAVID, Maurício Dias (Orgs.). Brasil-EUA: Antigas e novas perspectivas sobre sociedade e cultura. Rio de Janeiro: Leviatã, pp. 109-141.

DURKHEIM, Émile e MAUSS, Marcel (2013 [1902]). Algumas formas primitivas de classificação. Contribuição para o estudo das representações coletivas. In: BOTELHO, André (Org.) (2013). Essencial sociologia. São Paulo: Penguin Classics Companhia das Letras, pp. 222-290.

LÉVI-STRAUSS, Claude (1996 [1955]). Tristes trópicos. São Paulo: Companhia das Letras.

MELLO, Evaldo Cabral de (2002). Um imenso Portugal: História e historiografia. São Paulo: Editora 34.

MELLO, Luiza Larangeira da Silva (2012). A sensibilidade cosmopolita: sentimento histórico e anglofilia nas obras de Joaquim Nabuco e Henry James. Escritos, a. 6, n. 6, pp. 73-99.

MERQUIOR, José Guilherme (1977). De Anchieta a Euclides: Breve história da literatura brasileira. Rio de Janeiro: José Olympio.

MORICONI, Ítalo. Um estadista sensitivo: A noção de formação e o papel literário em Minha formação, de Joaquim Nabuco. Revista Brasileira de Ciências Sociais, vol. 16, n. 46, pp. 161-172, jun.

RICUPERO, Rubens (s.d.). Joaquim Nabuco In: ABREU, Alzira Alves de et al. Dicionário histórico-biográfico da Primeira República (1889-1930). Disponível em: $\quad<$ http://cpdoc.fgv.br/sites/default/files/verbetes/primeirarepublica/NABUCO,\%20Joaquim.pdf>. Acesso em: 10 jul. 2015.

SANTIAGO, Silviano (2006). Atração do Mundo (Políticas de Globalização e de Identidade na Moderna Cultura Brasileira). Contexto, a. 14, n. 13, pp. 11-29.

VENANCIO, Giselle Martins (2013). Comemorar Camões e repensar a nação: o discurso de Joaquim Nabuco na festa do tricentenário de morte de Camões no Rio de Janeiro (1880). Revista Brasileira de História, vol. 33, n. 65, pp. 277-290, jun.

VIVEIROS DE CASTRO, Eduardo. Metafísicas canibais: elementos para uma antropologia pós-estrutural. São Paulo: Cosacnaify, 2015.

Artigo recebido em 27 de outubro de 2015.

Aprovado em 11 de maio de 2017.

DOI: $10.12957 /$ intellectus.2017.31649 